\title{
ATEBE
}

Dinî Araștırmalar Dergisi

Journal for Religious Studies

ATEBE Dergisi / Journal of ATEBE

e-ISSN: 2757-5616| Haziran / June 2021/1, 5: 105-119

\section{Erken Dönemin Ahlâk Tasavvuru Doğrultusunda Tasavvufun Din Bilimleri Arasına Girmesi}

The Incorporation of Sufism into Religious Studies in Line with the Understanding of Morality of the Early Period

\section{Fatma Gülseroğlu}

Yüksek Lisans Öğrencisi, İstanbul Üniversitesi, Sosyal Bilimler Enstitüsü, Tasavvuf Anabilim Dalı M.A. Student, Istanbul University, Institute of Social Sciences, Department of Tasawwuf

İstanbul, Turkey

fatmaglser@gmail.com

orcid.org/ 0000-0002-0198-8132

\section{Makale Bilgisi / Article Information}

Makale Türü/Article Types: Araştırma Makalesi / Research Article

Geliş Tarihi / Date Received: 8 Mayıs/May 2021

Kabul Tarihi /Date Accepted: 29 Mayıs/May 2021

Yayın Tarihi / Date Published: 15 Haziran/June 2021

Yayın Sezonu / Pub Date Season: Haziran/June

Atıf / Cite as: Gülseroğlu, Fatma. "Erken Dönemin Ahlâk Tasavvuru Doğrultusunda Tasavvufun Din Bilimleri Arasına Girmesi $=$ The Incorporation of Sufism into Religious Studies in Line with the Understanding of Morality of the Early Period". ATEBE 5 (Haziran 2021), 105-119. https://doi.org/10.51575/atebe.935051

İntihal / Plagiarism: Bu makale, iTenticate yazılımınca taranmıștır. İntihal tespit edilmemiştir/This article has been scanned by iTenticate. No plagiarism detected.

Etik Beyan/Ethical Statement: Bu çalışmanın hazırlanma sürecinde bilimsel ve etik ilkelere uyulduğu ve yararlanılan tüm çalışmaların kaynakçada belirtildiği beyan olunur/It is declared that scientific and ethical principles have been followed while carrying out and writing this study and that all the sources used have been properly cited (Fatma Gülseroğlu).

Copyright (C) Published by Ankara Sosyal Bilimler Üniversitesi, İslami İlimler Fakültesi / Social Sciences University of Ankara, Faculty of Islamic Sciences, Ankara, 06050 Turkey. All rights reserved.

CC BY-NC-ND 4.0 | This paper is licensed under a Creative Commons Attribution-NonCommercial NoDerivatives International License. 


\title{
Erken Dönemin Ahlâk Tasavvuru Doğrultusunda Tasavvufun Din Bilimleri Arasına Girmesi
}

Öz

Ahlâk konusu dinler üstü konuşulan ve tartışllan evrensel bir olgudur. Her toplumun kendi sosyolojik ve psikolojik durumlarına bağlı olarak kabul ettiği ahlâkî değerler mevcuttur. İslam, Arap toplumuna geldiği ilk andan itibaren toplumun sahip olduğu ahlâkî değerleri düzenleme ve yenilemeye başlar. Düzenlenen ve yenilenen ahlâkî değerlerde örnek insan olarak ise Hz. Peygamber gösterilir. Bu çerçevede Hz. Peygamberin vefatından sonra İslam toplumunda oluşan karışıklıkların ahlâkî sonuçları ve toplum içinde bozulmalara tepki hareketi olarak ortaya çıkan sûfilerin eleştirileri meydana gelir. Her ne kadar fikıh ve kelam alanları teşekkül süreçlerinde farklı konular üzerinde tartışsalar da ahlâk konusuna ait özel bir bölüm fıkıh ve kelam alanında mevcut görünmez. Sûfiler, İslam din bilimlerinde ahlâk alanının göz ardı edilmesini eleștirir ve bu eksiliğin giderilmesi gerektiğini savunur. Erken dönemde yaşamış olan sûfiler ise bu açıklığın kapanması ve İslam düşüncesinin tekâmüle ermesi için çözümün tasavvuf olduğunu iddia ederler. Bu durumu meşrulaştırmak için de tasavvufun kelam ve fıkıh alanı gibi bir bilim olduğunu ispatlama yolunda eserler kaleme alırlar. Bu süreçte ise tasavvuf pratik ve zühd esaslı bir anlayıştan, diğer din bilimleri gibi bilgi çıkartan bir ilme dönüşür.

Anahtar Kelimeler: Tasavvuf, İlm-i Bâtın, Ahlâk, Âdâb, İstinbat.

\section{The Incorporation of Sufism into Religious Studies in Line with the Understanding of Morality of the Early Period}

\begin{abstract}
The issue of morality is a universal phenomenon that is spoken and discussed above religions. There are moral values that every society accepts depending on their sociological and psychological conditions. From the first moment Islam came to the Arab society, it began to organize and renew the moral values of the society. As a model of the regulated and renewed moral values, The Prophet is shown. In this context, the moral consequences of the confusion in the Islamic society after the death of the Prophet and the criticisms of the sufis who emerged as a reaction to the corruption in the society occur. Although the fields of fiqh and kalam discuss different issues in their formation processes, a particular section on morality does not appear to exist in the fields of fiqh and kalam. The sufis criticize the neglection of the field of morality in Islamic disciplines, and highlight the need of elimination of this deficiency. Sufis who lived in the early period claim that the solution that would fill this gap and help Islamic thought reach perfection is sufism. In order to justify this claim, they produce works attempting to prove that sufism is an independent discipline like kalam and fiqh. In this process, sufism transforms from a practical and ascetic understanding into a discipline that produces knowledge like other religious disciplines.
\end{abstract}

Keywords: Sufism, İlm-i Bâtın, Morality, Âdâb, Istinbat

\section{Extended Abstract}

The common problem that is generally discussed in heavenly religions and other beliefs is the question of how to eliminate one's moral deficiencies and reach perfection. This debate, which occurs in different forms in every thought system, has been seen under the title of "virtuous man" in philosophy since Socrates. In other words, the necessity of this process, which we will define as the moralizing process of the human, is based on the instinct of being perfect and flawless in human nature. When we look at the religion of Islam, the moral values that existed in the age of ignorance are rearranged in line with the Prophet and his teachings, since he was accepted as the model of the perfect human being. From the moment the religion of Islam came, Muslims endeavor to learn these revised moral values and how to apply them from the Prophet, and pursue their lives accordingly. After the death of the Prophet, different approaches and groups emerged in the Islamic society and there had been disagreements on many issues, including morality between these different approaches. The formation of kalam and fiqh before sufism seems to be among the reasons that delay the foundation of the moral issue. Although there had been some approaches to moral issues from a theological and juridical point of view, a fully composed deed of reason did not exist. Among the Islamic scholars, there are those who advocate the philosophical approach to morality as well as those who consider ethics to be included in the field of fiqh because it belongs to the realm of human acts. Mu'tezile can be given as an example for those who defend the philosophical moral approach. As a result of establishing his system of thought on the principle of justice, he 
argues that the mind of a person should be able to distinguish between right and wrong in order to be in a responsible state. In addition, within the framework of the moral problem, there is a group that emerged as a reaction to the sociological course towards the end of the first century. The reaction is that these people, who call themselves sufis, leave cities and turn away from society. Sufis reach at a certain position because the society respects them. Sufism's gaining reputation in the society causes some people with bad intentions to act as if they are the passengers of this road, although they are not among the sufis... Moreover, the increasing popularity of the sufis in society had been causing problems for the jurists, who had been ruling the cities, and also for Islamic scholars. In this respect, it is seen that the works written in the fourth and fifth centuries AH, namely in the establishment period of sufism, aims at placing the problems in the control of the system within a certain framework. In order to justify this situation, they write works to prove that sufism is an independent discipline such as kalam and fiqh. This process, which starts with Cuneyd-i Baghdadi, continues with Serrac, Kelabazi, Kuşeyri and Hücviri. In this process it was seen that; sufism is not just about conscientiousness and struggle. These are just the parts of the first stage of its method. The second stage of its method is the istinbat method, which is also the method of fiqh. It was explained that Serrac, who regarded fiqh and sufism as forms of Islamic law, described fiqh apparent 'ilm, and sufism as 'ilm. Sufism expresses that the lifestyle of the Prophet is conveyed to Muslims in every period. The nature of the adab sections in the sufi works reveals here. The ways of knowledge and reconciliation of the sufis, who emphasize the relationship between knowledge and action, differ according to their understanding of manners. For this reason, to examine $a d a b$ in the sufi works means to find evidence for sufism's claim. When we look at the Adab section from this aspect, it becomes clear why Serrac allocated the most extensive discussion to $a d a b$ in his work.

\section{Giriş}

Semâvi dinler ve sair inançlar dâhil genel olarak üzerinde tartışlan ortak problem, insanın noksanlıklarından arınıp kemale nasıl ereceği sorunudur. Her bir düşünce sisteminde farklı şekillerde zuhûr eden bu tartışma kendini felsefede Sokrates'ten itibaren "erdemli insan" başlığı altında gösterir. Bir diğer deyiş ile insanın ahlâklanma süreci olarak tanımlayacağımız bu sürecin elzem görülmesi insanın tabiatında var olan mükemmel ve kusursuz olma güdüsüne dayanır. İslam dinine baktığımızda ise, ahlâklı-kâmil insan olarak Hz. Peygamber kabul edildiği için cahiliye devrinde mevcut olan ahlâkî değerler vahiy ve onun öğretileri doğrultusunda yeniden düzenlenir. İslam dini geldiği andan itibaren Müslümanlar revizyon edilen bu ahlâkî değerleri ve onu tatbik etmeyi Hz. Peygamberden öğrenerek yașamlarını buna göre sürdürmeye çaba gösterirler. Hz. Peygamberin vefatından sonra ahlâk dâhil birçok konuda ihtilafa düşen İslam toplumu içerisinde farklı yaklaşımlar ve gruplar ortaya çıkar. Bu farklılığın temelde iki sebebi vardır; ilki toplum içi yaşanan siyasi ve sosyolojik hadiseler, diğeri ise fetihlerin geniş coğrafyalara yayılması sonucu tanıșılan kadim gelenekler... İhtiyaca binaen kelam ve fikhın tasavvuf alanından daha erken teşekkül etmesi, ahlâk konusunun temellendirilmesini de geciktiren sebeplerden biri olarak gözükür. Her ne kadar kelâmî ve fikhî açıdan ahlâka dair konular hakkında yaklaşımlar zuhûr etse de tam olarak müteşekkil bir ameli akıl tasavvuru vâkî olmaz.

İslam bilim adamlarının içerisinde ahlâkı, insan fiilleri içerisine girdiği için fıkıh alanına dâhil kabul edenlerin yanı sıra felsefi ahlâk yaklaşımını savunanlar da mevcuttur. ${ }^{1}$ Buna ek olarak ahlâk problemi çerçevesinde hicri birinci yüzyılın sonlarına doğru sosyolojik gidişata tepki mahiyetinde ortaya çıkan bir grup, hicri üçüncü yüzylla gelindiğinde ahlâk konusunda otorite sahibi olduğunu iddia eden bir zümreye dönüşür. Cüneyd-i Bağdâdî (ö.297/909) ile başlayan bu iddia daha sonra onun takipçileri olan Serrâc, (ö.378/988) Kelâbâzî, (ö.380/990) Kuşeyrî (ö. 465/1072) ve Hücvîrî (ö. 465/1072) tarafından devam ettirilir. Tasavvufun din bilimleri arasına girme süreci olarak kabul edilen bu adım, ahlâk konusu dıșında din bilimleri tarafından tasavvufa yöneltilen eleştirilerin müsebbibi olan mülhit grupların reddedilmesi amacını da taşır. Lakin bu hadise araştırmanın kapsamı alanına girmediği için derinlemesine bu konu üzerinde durulmayacaktır. Ele alınacak olan çalışmanın iki boyutu bulunmaktadır. Bunlardan ilki, İslam toplumunda ahlâkî yaklaşımların neler olduğunu araştırarak tasavvufun ahlâkî bakımdan din bilimlerinde neyi eksik gördüğünü saptamaya çalışmak. İkincisinde ise, ahlâkî yaklaşımlardaki eksikliğin saptanması sonucu erken dönem şârihleri tarafından tasavvufu belirtilen açıklık üzerine inşa etmeleri sürecini incelemek. Araştırmanın nihayetinde

\footnotetext{
1 Mustakim Arıcı, "İlimler Tasnifi Literatüründe Ahlâk İlmi", Mukaddime 7/1 (2016), 7.
} 
tasavvufu din bilimleri arasına girmesini ve kendi alanında özel literatür oluşturmasını sağlayan ahlâkın, tasavvuf açısından delillendirmesine ulaşmaya çalışılacaktır.

\section{Erken Dönem Din Bilimlerinin Ahlâk Tasavvuru}

Pratik bilgiler, bilginin belirli bir mefhuma çevrilmesinin yanı sıra eyleme geçirilebilmesiyle teorik bilgilerden ayrılır. Eyleme geçirilen pratik bilgilerin zamanla nefste bir bilinç meydana getirmesi ve bu işlemin devamlılık kazanması halinde huylar oluşur. ${ }^{2}$ Sözlük manası "seciye, tabiat ve huy" anlamlarına gelen hulk veya huluk kelimesinin çoğulu olan ahlâk kavramı buradan zuhûr eder. Bu meyanda bir tanımlama yapılacak olunursa; Ahlâkın insanın yapmış olduğu eylemlerin iyi veya kötü olarak nitelendirilmesi için insan davranışlarının genelini inceleyen bir bilim dalı olduğu söylenebilir. Dinin iki temel kaynağından biri olan hadisi şeriflerde de iyi ve kötü huyların izah edilmesinde ahlâk kelimesinin zikredildiği görülür. İyi ve güzel huylar için, hüsnü'l-huluk, mehâsinüll-ahlâk, mekârimü'l-ahlâk, el-ahlâku'l-hasene, elahlâku'l-hamîde terimleri, kötü ve çirkin davranışlar için de, sûü'l-huluk, el-ahlâku'z-zemîme, elahlâku's-seyyie terimleri yer alır. ${ }^{3}$ Hz. Peygamberin (s.a.s) ahlâk konusunda en mühim kabul edilen hadîs-i şerifi ise şudur; "ben güzel ahlâkı tamamlamak için gönderildim."4 $\mathrm{Bu}$ söz doğrultusunda Hz. Peygamberin gayesinin kendisinden önce var olan ahlâkı düzenlemek ve tamamlamak olmasına izafeten ahlâkın insan için mahiyeti ve insanın da asıl emelinin ahlâklanma olduğu anlaşılır. Genel olarak ahlâkî değerlere bakıldığında ise görülür ki, ister dini olsun ister seküler olsun ahlâk, insanların mevcut olduğu yerlerde mahiyet kazanır ve ahlâkî değerleri olmayan bir toplumun var olduğuna şahit olunmaz. ${ }^{5} \mathrm{Bu}$ doğrultuda ahlâkın insanın evvelemirde var olmasiyla birlikte var olduğu düşünülür. İnsanlara doğru yolu göstermek amacıyla gönderilen dinin en önemli sacayaklarından birinin ahlâk olduğu umumî olarak kabul edilir. Bu sebeple dini bütüncül bir şekilde anlamak için normatif ve kurumsal cihetlerinin yanı sıra dini-ahlâkî ilişkiyi de doğru bir şekilde kurmak elzemdir. Ahlâkî değerleri düzgün sistemleştirilmemiş bir dini inancın akıbeti, Hıristiyan Kilise otoritesinin nihayetinde yıkılması gibi bir sonuca maruz kalacağı kaçınılmazdır. Neticede İslam dinini Hıristiyanlık ve sair dinlerden ayıran en önemli husus da burada ortaya çıkar ki bu da, İslam'ın Tanrı-insan ilişkisinde tafsilatlı ve derin bir ahlâkî değerler anlayışına sahip olmasıdır. ${ }^{6}$

Din bilimleri arasında ilk olarak tedvin edilen fikıh alanının ahlâkî yaklaşımına değinmeden önce İslam'ın erken döneminde fıkıh kelimesinin salt normları kapsayan bir ilim dalı olarak telakki edilmediğini, bilakis kelime manasından mütevellit "dinde derin anlayışa sahip olmak" anlamında kullanıldığını ifade etmek gerekir. Fıkıh kelimesi özel bir alan olarak tahsis edilmeden önce sadece kuralları ihtiva eden bir anlamda kullanılmamaktaydı. Bilakis ilk asırda fakih kişi denilince akla şeriat kurallarına ek olarak Hz. Peygamber'in ahlâkına da hâkim kişi gelirdi. Bu bilgi göz önünde bulundurulduğunda hadîs-i şerif ve rivayetlerde geçen fakih kelimesinin ahlâkî konuları da içeren bütüncül bir anlamda kullanıldığı anlaşılmış olur. Nitekim rivayete göre Hz. Peygamber (s.a.s) şöyle buyurmuştur: "Allah hayrını dilediği kimseyi dinde fakih (ince anlayış sahibi) yapar." 7 Bir rivayette de şöyle geçmektedir; bir kişi Hasan-ı Basrî̀ye (ö.110/728) gelip; "Filan kişi fakihtir" dediğinde Hasan-ı Basrî ona; "Sen hiç fakih görmemişsin. Çünkü fakih dünyaya değer vermez, ahirete yönelir. Dini emirlere karşı basiretlidir" cevabını vermiştir. ${ }^{8} \mathrm{~Hz}$. Peygamberin hadis-i şerifinden ve Hasan-ı Basrî'den rivayet olunan fakih açılamalarına dikkat edildiğinde, fakihin anlamının daha kapsayıcı bir form içerdiği, zâhir yanında bâtın ilmine de vakıf olan birinin kast edildiği açığa çıkar. Fıkıh kelimesinin geniş kapsamlı kullanıldı̆̆ına dair bugüne ulașan ve ilk metinler kapsamına giren Ebû Hanîfe'nin (ö.150/767) Flkhu'l-Ekber'i kelâmî konuları içermesi hasebiyle erken dönemde fikha bakış açısını beyan eder niteliktedir.

Ömer Türker, Ahlâk (İstanbul: Ketebe Yayınları, 2020), 74.

Mustafa Çağrıcı, "Ahlâk", Türkiye Diyanet Vakfı İslam Ansiklopedisi (İstanbul: TDV Yayınları, 1989), 2/1-9.

Ebû Abdillâh Mâlik b. Enes el-Ashabî İmam Mâlik, el-Muvatta', nşr. Abdüvehhâb Abdüllatîf (Kahire: y.y., 1382/1962). " Hüsnü'l-Hulk", 8.

Türker, Ahlâk, 63.

Ali Bardakoğlu, "Ahlâkın Fıkıh Kuralları Arasında Buharlaşması", Eskiyeni 35 (2017), 59.

Ebü'l-Hüseyn Müslim b. el-Haccâc Müslim, el-Câmi 'u'ș-șahîhh, nşr. Muhammed Fuâd Abdülbâkī (Kahire: y.y., 1374-75/1955-56), “İmâret”, 175.

8 Ebû Nasr es- Serrâc, İslâm Tasavvufu: el-Lüma', çev. H. Kamil Yılmaz (İstanbul: Erkam Yayınları, 2016), 18. 
İslam bilim tarihinde ilk tedvin niteliğine sahip olan fikıh alanının ana gayelerinden biri olarak, "İslam ahlâkî değerlerin nesneleștirilmesi ve sosyolojik çevrelerce uygulanmasını sağlanması" ifadesine bakacak olursak, fıkıh ve ahlâk kavramının iç içe ayrılmaz bir şekilde olması beklenir. Nitekim fikıh bir bilim olarak tedvin edilmeden önce ayrışmalar başlamadığı için toplumda bütüncül bir zihniyet hâkimdir. Lakin ilk dönemlerde mevcut olan fikhın ahlâk ile bütünlüğü zaman geçtikçe fıkıh kurallarını uygulatma konusundaki yönetimin baskın tavrı sebebiyle ahlâk fikıh kurullarının gerisine düșer. ${ }^{9}$ Diğer bir ifade ile sosyolojik gelişmeler sonucu fikhın gayesi, içeriğe önem vermekten daha çok şeklin tam olmasıyla ilgilenir hale gelmiştir. Hâlbuki fıkhın toplumu düzenlemek için istinbat etmiş olduğu hükümlerin temelinde dinin ahlâkî değerleri bulunur. Örneğin fıkıh alanının kamuda sağlamaya çalıştığı adalet, özgürlük, iyiliğe teşvik-kötülükten sakındırma, vicdan bütünlüğü ve insan haysiyeti gibi değerler, kaynağı ahlâka dayanan değerlerdir. ${ }^{10}$ Ezcümle İslam hukuku asgari düzeyde ahlâkın kamu üzerinde yaptırım gücüne sahip olan bir kolu olarak teşekkül etse de zamanla bu yaptırımların bâtınî tarafı göz ardı edilerek zâhirî kısmında oluşumunu devam ettirdiği görülür. Araştırmanın ikinci kısmında ele alınacak olan ahlâkın İslam toplumundaki konumunun fikhî açıdan değişmesinin sebeplerinden birkaçı şunlardır; literal okuma bir diğer ifade ile zâhirîlik, şekilcilik, meseleci yöntem, makâsıd ve masâlih düşüncesinde daralma, yazının devamında da detaylandırılacak olan kelâmî açıdan hüsün-kubuh idrakinde daralma ve hile-i şeriyye vb. ${ }^{11}$

Fıkıh alanına benzer bir biçimde kelam alanında da ahlâk konusu tasavvuf ve felsefede olduğu gibi özel bir alana sahip değildir.12 Kelamda ahlâk ile alakalı yapılan tartıșmalar, bașka bir konunun bağlamı veya sonucu olduğu için yapılır. Bilhassa erken dönemde vuku bulan siyasi ve sosyolojik hadiseler sebebiyle sonucu temelde ahlâkî yaklașımları derinden etkileyecek tartışmalar zuhûr eder. Söz gelimi Emevi yönetiminin topluma karşı tutunmuş olduğu siyasi tavır, insan fiillerinin failinin kendisi olmadı̆̆ ve kader gereği istenmeyen savaşların ve olayların meydana geldiği inancıdır. Kader konusunda selefi anlayışı kabul eden Emevi yönetiminin uygulamış olduğu haksızlıkların sorumlusunu ilahi kadere bağlıyor olması sebebiyle, İslam toplum ahlâkının bariz bir șekilde tehlikeye düştüğü zamanın âlimleri tarafından beyan edilir. ${ }^{13}$ Yönetime karşı yapılan olumsuz bir söylemin -ki bu yönetimin her istediğini yaptıktan sonra mesuliyeti kadere bağlamasıdır- zuhûr ettiğini gören Emevi Halifesi Abdülmelik b. Mervan'ın (ö.86/705) dönemin saygın kabul edilen âlimi Hasan-ı Basrîyye kader ile alakalı görüşlerini sorduğu ve Hasan-ı Basrî̀nin de halifeye cevaben yazmış olduğu Risâle tartışma bağlamında temel dayanak olarak gösterilen yazıdır. Risalenin önemi Hasan-ı Basrî̀nin kulların fiilleri bağlamında görüşlerini ayet ve hadis odaklı akli yaklaşımlarla uygun tevil yapması hasebiyledir. Bu risalede Hasan-ı Basrî Emevi yönetiminin haksız yere yapmış olduğu zulmü Allah'a isnat ederek kendilerini temize çıkarmalarının doğru olmadığını ve böyle bir tutumun Allah'a yapılmıș bir iftira olduğunu ispatlamaya çalıșır. ${ }^{14}$ Her ne kadar Risale ahlâk başlığı altında yazılmış olmasa da insanın mükellefiyetini temellendirme konusu ahlâkî sonuçları olan bir problem olduğu için kelâmî olan bu metinde dönemin ahlâk anlayışına dair önemli bilgiler bulunur.

Bu dönemde kelam âlimleri tarafından ele alınan kulların filleri konusu kader bağlamında tartışılır ve yönetimin savunduğu görüşler, toplumda ortaya çıkabilecek ahlâkî bozulmaları içerdiği ilk olarak Mu'tezile tarafından iddia edilir. Mu'tezîlî âlimler, gevşeklik olarak gördüğü kulların mükellefiyetlerini kadere bağlama yaklaşımı karșısında sert bir tavır takınarak her bir kişinin yaptığı fiillerden sorumlu olduğunu savunur. Mu'tezilenin insanın eylemlerine karşı mükellef olduğu iddiası sebebiyle, modern dönem oryantalistlerinden Christopher Melchert Mu'tezileyi akli yaklaşımları baskın olduğu için akılcı bir fırka olarak bilinse de aslında İslam

9 Bardakoğlu, "Ahlâkın Fıkıh Kuralları Arasında Buharlaşması", 62.

10 Ahmet Yaman, "Fıkıh-Ahlâk İlișkisi İslâm Amelî Ahlâkının İlke ve Uygulamaları Çerçevesinde Bir Giriş", Usul İslam Araștırmaları 9/9 (2008), 101.

11 Bardakoğlu, "Ahlâkın Fıkıh Kuralları Arasında Buharlașması", 68-78.

12 Fethi Kerim Kazanç, "Mutezile Kelam Sisteminde Ahlâk Tasavvuru: Kâdî Abdulcebbâr Ekseninde Bir Değerlendirme", Journal of Islamic Research 27/3 (2016), 286.

13 Mustafa Çağrıcı, İslam Düşüncesinde Ahlâk (İstanbul: Dem Yayınları, 2018), 95.

14 Lütfi Doğan-Yaşar Kutluay, "Hasan Basrî'nin Kader Hakkında Halife Abdülmelik b. Mervan'a Mektubu", Ankara Üniversitesi İlahiyat Fakültesi Dergisi 3/3 ( 1954) 75-84. 
toplumunda ilk zühd hareketi olarak tanımlar. ${ }^{15}$ Bu tanımlamaya ek olarak Macid Fahri'ye göre de Mu'tezile İslam toplumu içerisinde ilk kez gerçek manada ahlâk konusunda konuşmuştur. Fahri, Mu'tezilenin iyi ve kötünün tabiatı, ilahi adalet ve kudret son olarak ahlâkî özgürlük ve sorumluluk meseleleri hakkında tartışma yaparak ahlâk alanında temelin atıldığını ifade eder.16 İslam bilim tarihine bakıldığında evvelemirde siyasi bir hadise problemi olan kader ve insan hürriyeti meselelerinin tartışılması sonucunda ilk ahlâkî yaklaşımların temeli atılmış olduğu görülür.

Emevi yönetiminin takınmış olduğu tavır iktidarın el değiştirmesi ve yerine Abbasi yönetiminin gelmesiyle neticelenir. Yönetimde gerçekleşen bu değişime müteakip Grek felsefesinin Arapçaya tercüme sürecinin başlaması ve İslam âlimlerinin felsefe ile tanışmasıyla dini-ahlâkî ve siyasi konularda akılcı yaklaşımlar kendini göstermeye başlar. Din bilim adamlarının arasında bu üslubu ağırlıklı olarak kullanan Mu'tezîlî âlimler olur. Bu meyanda ele aldıkları konular arasında ahlâk konusundaki yorumlarında da aklî üslûbu kullanırlar. Düşünce sisteminde adalet ilkesini temel alan Mu'tezile, aklın iyiyi ve kötüyü ayırması gerektiğini savunur ve aklın ahlâk konusunda kesin ve güvenilir bilgiye ulaşması için ahlâkî değerlerin değişmez olması gerektiğini iddia eder. ${ }^{17}$ Ahlâkî değerlerin değişmezliğinin kabulü ise, din ve aklın ahlâk konularına anlam yüklemediğini sadece özlerinde var olan niteliği ortaya çıkardığını kabul etmektir. Mu'tezilenin amacı ahlâkı bağımsızlığına kavușturmak ve izafiliği bulunmayan ahlâkî kuralları vahyin açıklamaları olmadan insan aklının bilebilmesidir. Bu görüşün mukâbili olarak, dünyanın muhtelif yerlerinde yaşayan toplulukların kabul etmiş olduğu birbirinden farklı ahlâkî yaklaşımların vukû bulmasını ise Mu'tezile, ahlâk kurallarının hakikatinin çokluğundan değil bilakis ahlâk hakkında tümel bir yaklașım bulunmamasının sebebini insanların hakikate dair eksik bilgiye sahip olması gibi farklı sebeplere dayandırır. ${ }^{18}$ Kötülüğü insana yükleyen Mu'tezile Allah'ı kötülük yapmaktan münezzeh kılar ve aslah teorisi gereğince yaratıcının kulları için sadece en iyisini yarattığını iddia eder. Kötülüğün kaynağını insan olarak belirlemek toplumda kadere sığınarak ahlâkî düzeni bozan kişilerin veya zümrelerin önünü kesmek amacı da taşır. Bu yaklaşımlar doğrultusunda insanın hür olması gerektiği ve işlemiş olduğu iyiliklerin karşılığında Allah'ın vaadine mazhar olacağı, kötülük işleyen kimselerin ise Allah'ın vaidi ile muamele olunacağını savunulur.

Ahlâkî problemler göz önünde bulundurarak düşünüldüğünde Mu'tezile'nin usul-i hamse olarak belirlediği beş ilkesinin ahlâk üzerine kurulduğu anlaşılır. İnsan fiillerinde özgür olması için Allah'ın adaletini temele yerleştirerek vaad ve vaid ilkesi ile kişinin mükellef olduğu ispatlanır. Bunun yanı sıra dinin iyiliği emredip kötülüğü nehyetmesi onun iyi ve kötü ayrımını kendisi yapması hasebiyle değil bilakis teşvik amacı taşıdığı içindir. Son olarak büyük günah işleyenin durumu hakkındaki görüşün de diğer ilkeler gibi aynı şekilde ahlâkî değerlere dayandığı görülür. Yukarıda zikredildiği üzere Mu'tezilede her ne kadar ahlâka dair kapsamlı bir kuram olmasa da muhtelif bașlıklar altında ahlâkî değerler üzerine tartıșıldığı vâkîdir. ${ }^{19}$ Buna örnek olarak, Husün-kubuh, salah-aslah, ef'âlü'l-lbâd, kaza-kader, et-ta'dîl ve tecvîr, zulüm, zarar, adalet, fayda ve acı (elem) konularını verebiliriz.

Mu'tezile'nin adalet ilkesi eksenli ahlâkî değerlere yorumu mukabilinde Eş'arî düşünce, Allah'ın kudret sıfatını temele alarak kulların filleri hakkındaki ahlâkî görüşünü ortaya koyar. Kelam alanının ahlâk konusu hakkındaki görüşlerin bir tarafı Mu'tezile olurken bunun muhalif kanadını Eş'arî nazarisi teșkil eder. Ahlâkî değerleri içine alan ef'âl-i ibâd konusunda Eş'arî düșünceyi Mu'tezileden ayıran hususa gelecek olursak iyinin, kötünün ve ahlâkî yargıların insan aklı ile bilenemeyeceği, aksine fiillerin değer yargılarının Allah tarafından belirlendiği iddiasıdır. İyi ve kötünün ilahi hitap sonrasında bilinebilecek olan hususlar olmasının yanı sıra, kişinin mükellefiyeti de ancak bu hitaptan sonra tahakkuk eder. Selefi düşünceyi takip eden Eş'arî,

15 Christopher Melchert, Sünnî Düşüncenin Teşekkülü, çev. Ali Hakan Çavuşoğlu (İstanbul: Klasik Yayınları, 2018), 301.

16 Kazanç, "Mutezile Kelam Sisteminde Ahlâk Tasavvuru: Kâdî Abdulcebbâr Ekseninde Bir Değerlendirme", 288.

17 Mustafa Çağrıcı, İslam Düşüncesinde Ahlâk (İstanbul: Dem Yayınları, 2018), 99.

18 Çağrıcı, İslam Düşüncesinde Ahlâk, 100.

19 Kazanç, "Mutezile Kelam Sisteminde Ahlâk Tasavvuru: Kâdî Abdulcebbâr Ekseninde Bir Değerlendirme", 289. 
(ö.324/935) şerrin Allah tarafından olduğunu ve onu kendisinden gayrısı için yarattığını aktarır. Diğer bir deyiş ile kendi indinde herhangi bir değeri olmadığı için şerri yaratanın Allah olduğunu iddia etmek de sorun teşkil etmeyecektir. ${ }^{20}$ Bu konu hakkında Cüveynî (ö.478/1085) ise, "bir șey sadece kendisi, türü ve ayrılmaz niteliği itibariyle iyi değildir. Kötü olan șeyler hakkında da durum böyledir. Bazen kendisinde bulunan genel özellikleri itibariyle kötü olan bir șey, şer'an iyi olabilir" beyanında bulunmuştur.21 Açıklamadan yola çıkılacak olursa Cüveynînnin iyi ve kötünün yaratılış itibari ile belirlenmediği ve şeylerin hakkında yargının sadece vahiy ile bileneceği iddiasına varılır. Bu meyanda Cüveynî iyi ve kötünün insan aklı tarafından belirlenebilmesinin zaruri olduğunu iddia edenlerin, neyin iyi neyin kötü olduğu konusunda ihtilafa düşmelerinden dolayı kendi kendilerini reddettiğini zikreder. ${ }^{22}$

İnsanın eylemlerinde Mu'tezile gibi kudret ve irade kavramlarını kullanmayı Allah'ın kudret ve iradesine helal getireceğini düşünen Eş'arî kelamcılar insan için bunları kullanmaktan imtina ederler. Bu iki kavramı kullanmaktan kaçınmak insanın sorumluluğunu tehlikeye düşüreceği için de kulun mükellefiyetini korumak adına farklı teoriler geliştirmeye teveccüh edilir. Eș’arî, Mu'tezilenin fiilin failini belirlemede kullanmıș olduğu yaklașımına alternatif bir yaklaşım olarak kulların filleri için kesb kavramını kullanır ve Allah istemediği müddetçe kulun bir fiili kesb etmesinin imkânsız olduğunu vurgular. ${ }^{23}$ Eş'arî’nin öne sürdüğü kesb teorisine göre insan fiilinin iki veçhesi vardır; bunlardan birisi yaratma bakımından Allah'a nispet edilirken bir diğeri ise, hâdis olan insan istitâatine dayanır. Kulun istitâatının kabulü ve yaratma fiilini Allah'a isnat edilmesi sayesinde hem insanın eylemlerindeki sorumluluğu hem de Allah'ın kudret ve irade sıfatları korunmuş olur. Bu meyanda ahlâk konusu dâhil hiçbir şeyin Allah'ın irade ve kudretinden ayrı müstakil olamayacağını savunan Eş'arî kelamcılar, insan aklını ahlâkî değerleri belirlemede ön plana çıkaran Mu'tezile kelamcıları ile çatışır. Ahlâkî değerler ilahi hitap ile belirlenmediği zaman geriye insan fitratı ve faydacılık ilkesi kaldığını izah eden Eş’arîler, her kişinin farklı bir bakış açısına sahip olduğu için böyle bir yaklaşımın nihayetinde nesnel bir hakikate ulaşmanın imkânsızlığını beyan ederler. ${ }^{24}$ Eş'arîlere göre, genel ve nesnel bir ahlâkî değerler sistemini kurmanın imkânı sadece ilahi irade ile gerçekleşir. Lakin Eş'arîlerin anladığı anlamda Allah'ın iradesi ve kudreti karşısında kulun nasıl bir ahlâkî hayat yaşayacağı sorusunun tatminkâr cevabı olmaması, Eş'arî kelamcılar için bu konunun ikincil bir öneme sahip olduğu gerekçesiyledir.

Ehl-i Sünnet kelamının diğer kolu olarak nitelendirilen Mâtürîdîliğin kurucusu olan Ebû Mansûr el-Mâtürîdî'nin epistemolojisinde akıl, en önemli dayanaktır. ${ }^{25} \mathrm{Bu}$ yargının en bariz delili Mâtürîdî'nin Kitabu't-Tevhîd'de aklı "her türlü işin kendisine dayandırılması gereken bir temel (asıl)" olarak tanımlamasıdır. ${ }^{26}$ Düşünce sisteminin her alanında etkili olan akıl, ahlâkî değerleri belirlemede de Mâtürîdînin sıkça vurgu yaptığı bir ilke olarak karşımıza çıkar. Mu'tezile ve Eş'arî'nin iyilik-kötülük yaklaşımına farklı olarak Mâtürîdî, "insan aklı" ve "insan tabiatı" ( $t a b$ ' șeklinde ikili bir tasnif izah eder. ${ }^{27}$ İnsan tabiatına iyi ve güzel gelen bir șey, insan aklı için kötü ve zararlı olabilir. Yine aynı şekilde insan aklına iyi ve güzel olan ise, insan tabiatına kötü ve zararlı gelebilir. İnsanın tabiatı psikolojik ve sosyolojik hadiselerden etkilendiği için ahlâkî değerler algısında farklılık ve değişim olması genel bir durumdur. ${ }^{28} \mathrm{Bu}$ sebeple Mâtürîdî, bu nev'inden hadiseler meydana geldiğinde dayanak noktası olarak alınanın akıl olması gerektiğini açılklar. Bu açılamaya göre iyilik-kötülük problemini doğru bir şekilde anlamanın yegâne koşulu, evvela insan tabiatı ile aklını birbirinden ayrı olarak ele alınmasıdır.

20 Çağrıcı, İslam Düşüncesinde Ahlâk, 101.

21 Cüveynî, Kitâbü'l-İrşâd İnanç Esasları Kılavuzu, çev. Adnan Bülent Baloğlu vd. (Ankara: Türkiye Diyanet Vakfı Yayınları, 2016), 216.

22 Cüveynî, Kitâbü'l-İrşâd, 217.

23 Ebû'l-Hasan el- Eş'arî, el-íbâne ve Usûlü Ehli's-Sünnet Eş'arî Akâidi, çev. Ramazan Biçer (İstanbul: Gelenek Yayıncilık, 2010), 79.

24 Hulusi Arslan, "Ahlâkî Değerlerin Nesnelliği ve Öznelliği Açısından Mu'tezile ve Eş'arîlik", Hikmet Yurdu Düşünce-Yorum Sosyal Bilimler Araștırma Dergisi 9/17 (2016), 16.

25 Fatih İbiş, "Mâtürîdî'de İman-Ahlâk İlişkisi", Kelam Araştırmaları Dergisi 13/2 (2015), 718.

26 Ebû Mansûr el- Mâtürîdî, Kitâbü't-Tevhîd, çev. Bekir Topaloğlu (Ankara: İSAM Yayınları, 2017), 436.

27 Mâtürîdî, Kitâbü't-Tevhîd, 435.

28 İbiş, "Mâtürîdî'de İman-Ahlâk İlişkisi", 719. 
İnsan aklının iyi ve kötü olarak gördüğü șeyleri iki kısımda ele alan Mâtürîdî, bunlardan ilkinin özü itibariyle iyi ve kötü olduğunu diğerinin ise kendi dışında meydana gelen muhtelif sebepler yüzünden iyi ve kötü olarak nitelendirildiğini zikreder. Asli itibari ile iyi ve kötü olan şeyler hak veçhinden belirlenen fiiller kapsamına girer. ${ }^{29}$ Nitekim ilkine örnek olarak, adalet akıllarda yaratıcı tarafından değişmez bir şekilde iyi olarak betimlenirken, zulüm kötü olarak belirlenmiştir. Yine Mâtürîdî̀ye göre kendisi dışındaki durumlara bağlı olan şeylerin iyi veya kötü olarak nitelendirilmesinde insan aklı bir yol göstericiye ihtiyaç duyar. Bu izafiliğin oluştuğu konularda ise insan aklına yol gösteren karizma kişi peygamber olur. ${ }^{30}$ Söz gelimi fillerin hangi durumlarda ibadet sayılacağı, hangi durumlarda ise küfür sayılacağı yaratıcının göndermiş olduğu nübüvvet tarafından belirlenir. Bu ifadelerin anlaşılması için konuyla alakalı olan Nûreddin es-Sâbûnî'nin secde örneğini vermek yerinde olacaktır. Sâbûnî secde etmenin tek başına bir anlam ifade etmediğini, secde eğer Allah'a edilirse ibadet yani güzel ve iyi sayılacağını, bunun dışında herhangi bir şeye secde edildiğinde ise küfür ve kötü sayılacağını vurgular. ${ }^{31}$

İnsanın istitâati konusunda genel çerçevede bakıldığında Mâtürîdîliğin Eş’arîlik gibi kesb teorisini savunduğu görülür. Her ne kadar söylem açısında bir benzerlik vâkî olsa da içerik bakımından kesbe yüklenilen anlam her iki mezhep açısından farklılık arz eder. Eş'arîler kesb teorisini kesb-halk düzleminde alırken Mâtürîdî, fiil-halk bakımından ele alır. ${ }^{32}$ Yukarıda da zikredildiği üzere, Eş’arî kesbi daha önceden var olan bir șeyi kulun elde etmesi olarak tanımlar. Mâtürîdî ise, fiilin failliğinin insana ait olması cihetinden konuyu inceler. Mâtürîdî, akli ve nakli delilleri birlikte kullanarak fiilleri hakikat açısından hem Allah'a hem de kula nispet edilmesinin en isabetli görüş olduğunu iddia eder. Bu görüşün sağlamasını ise şu şekilde yapar; insanın aklının ve iradesinin ermediği fiiller mevcutken, planlarının sonucu vuku bulan ameller de mevcuttur. İlk vâkî olan hadisede kul atıl bir durumdadır. İkinci fiilde ise fail olanın kul olduğu açıtıtır. Ellerinin titrediğini fark eden bir adamın daha sonra titremesini kendi iradesi ile yapması arasındaki fark bu düzlemde ortaya çıkar. ${ }^{33} \mathrm{Bu}$ ifadelere ek olarak Mâtürîdî'yi Eş'arîlikten ayıran en mühim fark yaratma fiilini kesbe bağlı kılmasıdır. Buna göre yaratmanın gerçekleşmesi için insanın kesb etmesi ve bu kesbin ortaya çıkması için de insanın tercihlerinde hür olması elzemdir. ${ }^{34}$ Aksi takdirde irade olmaksızın kesbin, kesb olmaksızın da yaratmanın vukû bulması mümkün değildir.

Genel olarak kelam alanında ahlâk konusu incelendiğinde tartışmaların salt ahlâkî değerler adı altında olması yerine dolaylı bir şekilde insan fiilleri, iyilik ve kötülük kavramı üzerinden görüş beyan edildiğine şahit olunur. Çalışmanın birinci aşamasında yapılan incelemeler makro bir bakış açısına sahip olması gerekçesiyle olayların ve görüşlerin detaylarına girilmeden ana görüşler ve neticeler üzerinde durulmuştur. Erken dönemin ahlâkî yaklaşımının çerçevesini daha belirgin çizebilmek için detaylı ve ince bir araştırma yapılması gerekir. İlk bölüme hülasa bir şekilde bakılacak olunursa; yazıda ele alınan düşünce sistemlerinin muhtelif yönlerine ağırlık vermeye çalışılarak, ahlâkî değerleri belirleme açısından farklı yaklaşımlar elde edildiği görülür. Bu yaklaşımlardan ilki Mu'tezileye ait olup adalet ilkesi gereği, insanın mükellef bir durumda olması için kişinin aklının nakil olmaksızın doğruyu ve yanlışı ayırt edebilmesi gerekir. Bu görüşün aksi sayılabilecek Eş'arîliğin yaklaşımı ise, Allah'ın iradesi ve kudreti temelli insanın fiillerini yaratmada atıl olduğu, yalnız fiili kazanmada yani kesb etmede bir yerinin olduğu teorisidir. İnsanın fillerinde istitâatini kesb kapsamında ele aldıkları ve Allah'ın kudretine helal getirecek herhangi bir şeyi kabul etmedikleri için yaratıcı karşısında kulun ahlâkî değerleri nasıl yaşayacağı sorusu cevapsız kalır. Son yaklaşım olan Mâtürîdî’nin konuya çözümü diğer yorumların orta yolunu bulma çabasına benzer. Mâtürîdî, Mu'tezile gibi aklı her şeyin dayandırılması gereken bir temel olarak görürken detaylandırılması gereken hadiselerde ise, nübüvvete yani nakle ihtiyaç duyulacağını iddia ederek Eş'arî 'ye yakın durmuştur. İnsan aklının nakle, naklin ise insan aklına tabi olması gereken yerler farklılık arz eder. İbadet amaçlı fiillerde dayanak nakil destek de akıl iken, ahlâkî

Mâtürîdî, Kitâbü't-Tevhîd, 425.

Mâtürîdî, Kitâbü't-Tevhîd, 430.

Nûreddin es- Sâbûnî, Mâtürîdiyye Akaidi, çev. Bekir Topaloğlu (İstanbul: İFAV Yayınları, 2017), 128.

İbiș, "Mâtürîdî’de İman-Ahlâk İlișkisi", 724.

33 Mâtürîdî, Kitâbü't-Tevhîd, 445-446.

34 İbiș, "Mâtürîdî'de İman-Ahlâk İlişkisi", 726. 
değerleri belirlemede akıl dayanak nakil de destek konumunda olur. Ahlâk meselesi fikıh açısından ele aldığında ise şu görülür; Kur'an-ı Kerimden hüküm istinbat eden âlimler belirli bir döneme kadar zâhirî amelin yanında hükümlerin hikmetini de arayışı çabasındalar. Lakin asgari ahlâk olarak nitelendirdikleri toplumu düzenleyen hukuk kuralları zamanla otoritenin sarsılmaması gibi hadiseler sebebiyle içerikten daha çok resme önem veren bir alan haline gelir. Zâhirî ilim olarak isimlendirilen ve șehirde otorite sahibi olan bu din bilimlerinin ahlâkî değerler açısından bozulmaya başlaması sûfilerin tepki vermesiyle sonuçlanır. Tasavvuf her ne kadar eleștirel bir söylem șeklinde zuhûr etse de zâhirî ilimlerin karşısında durması için onlar gibi bir dini ilim olduğunu ispat etmesi gerekir. Bu meyanda yazının ikinci aşamasına geçerek tasavvufun iddiasını ispatlama meselesi incelenecektir.

\section{Tasavvufun Meşruiyet Süreci}

\subsection{Bir Din Bilimi Olarak İlm-i Bâtın}

Müslümanların fetihler sonucu yeni medeniyetler ile tanışması ve kadim otoriteler karşısında söz hakkı sahip olmaya gayret göstermesi sonucunda ilimlerin tedvin edilme süreçleri başlar. İslam âlimlerinin tedvin sürecinde birbirlerinden kopuk bir şekilde ilerleme kaydettiğini düşünmek büyük bir hata olur. Bilakis İslam bilimlerinin her bir kanadı, birbirine bağlı müşterek bir akıldan ilerleme kaydederek oluşumlarını tekâmüle erdirir. ${ }^{35}$ Tasavvuf harici diğer ilimler bilim olarak ilerleme sağlarken, tasavvuf pratik alanda gelişen bir hareket olarak karşımıza çıkar. Toplum içinde gelişen bir alan olması ve sistem içerisinde kurumsallaşmaya karşı isteksizliğin bulunması hasebiyle bilim içerisinde yerini en son Tasavvuf alır. Tasavvufun ilk olarak halkın içinde oluşması, İslam toplumunda sosyal hayatın ekonomik, siyasal ve kültürel açıdan değişiklere uğramasının bir tezahürüdür. Dünya hayatından yüz çevirmek ve benzeri anlamları içeren zühd kavramı, erken dönem sûfilerin Müslümanların yaşamış olduğu hayata takınmış oldukları tavrın genel adı olarak kabul edilir.

Sûfilerin topluma karşı gösterdiği bu tepki sosyal hayatın şu üç merhalesinde karşımıza çıkar; ilki kamu yönetiminden kaçınmadır. Bu tavrı takınan kişilerin arasında idari görevlerden kaçınan zahitlerin dışında görevden ayrılarak zühd yolunu seçenler kimselerin de mevcut olduğu görülür. İkincisi, refah seviyesini yükseltecek her türlü dünyevi meşgaleyi küçük görmedir. Zâhid bir yaşamı temsil eden ve tasavvuf için en önemli nitelik olan yoksul bir hayatı tercih etmenin ehemmiyeti, sûfilerin kendilerini fakirler ve miskinler olarak adlandırmasından belli olur. Üçüncü olan son merhale ise, fikıh-kelam gibi din ilimlerinin tedvin süresini kapsayan bu dönemde ilmi çalışmalara önem vermemedir. İlk sûfiler nezdinde ibadet ve amelin öncelikli konuma sahip olmasının yanı sıra tasavvufu bilimin bir yöntemi olarak tasavvur etmedikleri için kendilerini din bilimlerinden birine dâhil görmezler. ${ }^{36}$ Bahsedilen tepki İslam toplumunda tek bir şekilde zuhûr etmediği için bu tavrı takınan sûfilerin bazılarına șehri terk etmeleri sebebiyle "Gurebâ", bazılarına çölde gezinmeleri ve mağarada kalmaları hasebiyle "Şikeftiyye" ve bazılarına da yerleşik hayat yerine konargöçerliği tercih etmeleri sebebiyle "Seyyâhîn" isimleri verildiği aktarılır. ${ }^{37}$ Toplum tarafından eleștiriye maruz kalan sûfilerin durumları konunun ikinci aşamasına dâhil olduğu için, yazının devamında ilk olarak sûfilerin İslam toplumuna getirdiği eleștiriler ve bu eleştirilerin muhtemel sebeplerinden bahsedilecektir.

Müslümanların hicri ikinci asrın sonları ve üçüncü asrın bașlarındaki ilmi ve içtimai durumlarına eleștiri olarak Muhasibi'nin (ö.243/857) er-Ri'âye li-Hukukıllâh ve'l-Kıyâm Bihâa eserine şu şekilde başladığı görülür. "Haris dedi ki: Senin Allah hakkı ve ona uyma konusunda sorduğun şeye gelince; doğrusu sen asrımız insanlarının tümünün yerine getirmeyip zayi ettiği öyle önemli bir şey sordun ki, Allah onu korumak için peygamberlerini ve sevdiği insanları görevlendirmiştir." ${ }^{38} \mathrm{Bu}$ ifadelerde çok ciddi bir toplum eleştirisi ile karşı karşıya kalınır. Muhasibi'nin ifadesinde görülen Allah hakkına riayeti toplumun unuttuğu iddiası, Sûfiler ve din bilimleri arasında çekişmeli bir ilişkinin doğmasına sebebiyet verir. Sûfiler bu konu meyanında

35 Bu konu hakkında detaylı bilgi için bk. Ekrem Demirli, "Klasik Düşünce Okulu-Hucviri Keşfu'l Mahcub", Youtube (18 Mart 2019), 1. Ders, 00:16:00-00:18:50.

36 Ekrem Demirli, İslam Metafiziğinde Tanrı ve İnsan: İbnü'l Arabî ve Vahdet-i Vücûd Geleneği (İstanbul: Alfa Yayınları, 2017), 130-135.

37 Kelâbâzî, Doğuş Devrinde Tasavvuf: Ta'arruf, çev. Süleyman Uludağ (İstanbul: Dergâh Yayınları, 2013), 56.

38 Hâris el- Muhâsibî, Kalp Hayatı, çev. Abdülhakim Yüce (İstanbul: Işık Yayınları, 2005), 43. 
fıkıh ve kelamı zâhir ehli olarak niteler ve nasların sadece normatif bilgi aktarmadığını ifade ederek bilgi-eylem ilişkisinin hem zâhir hem de bâtınî nitelikler ile fiiliyata geçirilmesinin gerekliliğini vurgular. ${ }^{39}$ Ebu Talip el-Mekki (ö.386/996) ise, dünya âlimi ve dille âlim olarak nitelendirdiği zâhir ehlini keskin bir üslup ile eleştirir. Döneminde gerçekleșen bu durumun müsebbibini ise öğrendikleri ilim ile amel etmeyen ve menfaatleri uğruna fetva veren âlimler olarak görür. Bunun yanı sıra Mekki zâhir ilminin bâtınî ilim ile tamamlanacağını ifade etmek üzere Hz Peygamber'in "Müftüler sana fetva verse de sen yine kalbine danış, fetvanı kalbinden al" 40 hadîs-i șerifini aktararak kalp ilmine dikkat çeker. ${ }^{41}$

Zâhirî âlimleri eleştiren bir diğer sûfi Hakîm et-Tirmizîye (ö.320/932) gelecek olursak; o zâhirî ve bâtınî olarak fıkhı iki kısımda ele alan ilk kişi olarak kabul edilir. Zâhirî fıkhı, fakihin Kur'an-ı Kerimden ve sünnetten meselelere dair hükümleri çıkarması yani diğer bir ifade ile fıkhın fer kısmını kapsayan bölüm olarak nitelendirir. Bâtınî fıkhı ise, hakikate mutabık olarak kalbe gelen düşünceleri ortaya çıkarmak suretiyle oluşan ve fıkhın asl kısmını teşkil eden alan olarak belirler ${ }^{42}$ Hasan-ı Basrî̀ den nakledilen gerçek fakih tanımlamasına uygun olarak Hakîm et-Tirmizî de zâhirî ve bâtınî fıkhı birleștirebilen kişinin asıl fakih olduğunu beyan eder.43 Kendisinden sonra yapmış olduğu zâhirî ve bâtınî fıkıh ayırımını alarak tasavvufun mesailini netleştiren ve tasavvufa dini bilimler arasında yer açma imkânını bulan Serrâc ise; fıkhî ahkâmın insanın hayatında belki bir kez gerekli görünecekken tasavvufu ilgilendiren hal, makam ve mücâhede gibi bâtınî konuların bütün inanan kimselerin öğrenmesi gereken konular dâhiline girdiğini ifade ederek tasavvufun elzemliğine vurgu yapar. Genel itibariyle bakıldığında tasavvufun bilgi-eylem problematiğine yaklaşımlarından anlaşılıyor ki; sûfiler, Müslümanların bilgi-eylem ilişkisindeki mevcut olan bağı koparmasının neticesinde ilmî ve içtimâî tabakalarda yozlaşmasının oluştuğunu iddia ederler.

Sûfilere yönelik eleştiriler göz önüne alındığında odak noktası olarak fakirlik, tevekkül ve rıza kavramları çerçevesinde zühd hayatını tercih eden kimselerin geçim için çalışmayı küçümsemesi ve bunun neticesinde tasavvuf içerisinde cüz'i bozulmaların zuhûr ettiği görülür. Bozulmalara imkân tanıyan diğer bir konu ise, kelâmî tartışmalarda da yer alan kulların fillerinin kime nispet edileceği mevzusudur. Kelam alanında daha önce malumat verilen kulun fiilinde etken ve edilgenliği hakkında sûfiler, nefsi yok sayıp fiilleri Allah'a nispet ederek tevekkülü benimsemeyi kabul ederler. Fiillerin insana nispeti durumu ise yaratıcıya şirk koşmak anlamında ele alındığı için bu görüş reddedilir. Kulların eylemleri hakkındaki yaklaşımların bu doğrultuda olması sûfiler arasında bazı toplulukların mükellefiyeti hafife almalarına veya amelleri terk etmelerine sebebiyet verir. Bir diğer ifade ile zühd kavramının "eylemsizlik" anlamında mütalaa edilmesi sûfiler içerisinde kabul edilmeyecek yaklaşımların doğmasına imkân tanır. Tam manasıyla bu yaklaşımı savunan kişilerin kimler olduğu bilinmese de ibâhîlik adı altında söz bahis edilen İbâhîlerin, yaklaşımı farklı sonucu aynı olan iki görüşleri mevcuttur. Bunlardan ilki, kullar eylemlerinde özgür olmadığından dolayı cebr söz konusudur ve bunun neticesi olarak da insan fiillerinin bir anlam ifade etmediği düşüncesidir. İkincisi de, zühd hayatı yaşayan kişilerin belirli bir zamandan sonra ulaştıkları mertebenin gereğince kendilerinden mükellefiyetin düştüğü görüşüdür. ${ }^{4}{ }^{4}$ Her iki görüșün neticesinde insanın mükellefiyetini reddetme olayı mevzu bahistir. İslam toplumu içerisinde sorumlulukların hepsini reddeden bir zümrenin oluşması ve toplum bütünlügünü bozan hadiselerin meydana gelmesi hem tasavvuf kanadından hem de sair din bilimleri tarafından tenkitlerin yükselmesiyle sonuçlanır. Bu doğrultuda incelendiğinde Tasavvufun tedvin süreci için dayanak noktası olarak alınan hicri dördüncü ve beşinci yüz yıllarda yazılan eserlerin de sistemin içeri ve dışarısında mevcut ve

39 Hacı Bayram Başer, Şeriat ve Hakikat (İstanbul: Klasik Yayınları, 2017), 157.

40 Ebû Abdillâh Ahmed b. Muhammed b. Hanbel eș-Şeybânî Ahmed b. Hanbel, el-Müsned, nșr. Ebû Hâcir Muhammed Saîd Besyûnî (Beyrut: y.y., 1405/1985.), 1/194, (No. 17545).

41 Ebû Tâlib el- Mekkî, Kalplerin Azığı, çev. Muharrem Tan (İstanbul: İz Yayıncılık, 2018), 1/392.

42 Hakîm et- Tirmizî, Kalbin Anlamı: Beyânü'l-Fark, çev. Ekrem Demirli (İstanbul: Hayy Kitap, 2013), 78.

43 Hacer Nur Babacan, Erken Dönem Tasavvufunda Akıl-Ahlak İlișkisi (İstanbul: İstanbul Üniversitesi, Sosyal Bilimler Enstitüsü, Yüksek Lisans Tezi, 2019), 8.

44 Bașer, Seriat ve Hakikat, 68. 
kontrolü kaybedilmiş olan uygulamaları belirli bir çerçeveye yerleştirme gayesi taşıdığı görülür.45

Sûfiler dâhil icmaen bilim adamlarının ilim derken kast edilenin ne olduğu konusunda ittifak oldukları görüș șudur; bir alanın bilim olabilmesinin șartlarından biri, diğer bilimler arasında kendisine münhasır bir yer inşa etme yetisine sahip olmasıdır. Bir diğer ifade ile bir düşünce sisteminin ilim olabilmesi için mevzu, mesâil ve mebâdi' ye yani belirli bir konuya, meselelere ve ilkelere sahip olması gerekir. ${ }^{46}$ Tasavvuf toplumdaki kabul görülmüș olan bilimlerin arasına girebilmek için evvela kendi konuları haricinde kalan hususlarda otorite sahibi alanların hükümlerine tâbi olduklarını ileri sürer. Toplumda yerleşik gücü temsil eden fikıh ve kelam bilimlerinin kapsamına girmeyen ahlâk konusunda ise Tasavvuf Kur'an-ı Kerim'den hüküm istinbat gücünün kendi tekelinde olduğunu iddia eder. Buradaki iddiada yanlış anlaşılmaması gereken konu şudur; Tasavvuf toplumda bir ahlâk nazarisi olmadığı için ortaya çıkmamıștır. Haddi zatında konuyu bu şekilde anlamak İslam toplumunda ahlâk yoksunluğu olduğu düşüncesine götürür. Bir bilim olma sürecine giren tasavvufun gayesi ahlâkın varlığını ispatlama değil onun ne șekilde tahsil edileceğidir.47

İlk asırda içlerinde "ilmi çalışmalardan uzaklaşma" da bulunan kimi zümrelere karşı eleştirel bir söylem olarak çıkan tasavvufun hicri dördüncü asra geldiğinde tepkilerinin ilmi aşamasında geri adım attığı görülür. Elbette ki bunun sebebi olarak yukarıda zikredilen toplum içinde tasavvufu suiistimal eden grupların zuhûr etmesi ve toplumda otorite sahibi olan ilimlerin arasında ahlâk konusunun meşru bir zemininin olmaması kabul edilir. Sûfiler ahlâklanma sürecini engelleyecek herhangi bir meşgaleyle ilgilenmeyi kerih gördükleri için kendileri de vakıanın bu aşamaya gelmesinden rahatsız olurlar. Öyle ki Serrâc ile aynı dönemde yaşamış olan Kelâbâzî et-Ta'arruf eserinde tasavvufun eskisi gibi olmamasından adeta "sorucevaba" dönüşmüş bir durumda olmasından yakınır. ${ }^{48}$ Erken dönem şârihlerinden olan Serrâc ise bu meyanda Tasavvufa din bilimleri arasında yer açma amacıyla ilk sistematik eser yazan isimdir. Bu sebeple tasavvufun tedvin süreci incelendiğinde Serrâc'in el-Luma eseri kaynak kabul edilen sair eserlerden farklı bir öneme sahiptir.

Serrâc eserinde tasavvufun önemini ispat etmek için evvela ona ait bir alan belirler. $\mathrm{Bu}$ işlemi yapmadan önce din bilimlerinin mevzu ve yöntemlerinden bahsederek tasavvufa alan açan ve ilimler hiyerarşisi denilebilecek bir tasnife giden Serrâc, iddiasına dayanak olarak meşhur Cibril hadisini gösterir. Serrâc'a göre Cibril hadisinde geçen İslam, iman ve ihsan kavramlarının yerini dolduran üç tür ilim vardır. Bunlar da, Kur'an-ı Kerim ilmi, sünnet ilmi ve iman hakikatleri ilmidir. ${ }^{49}$ Serrâc'ın yapmış olduğu ayrıştırmaya göre tasavvufun mevzusu hadiste geçen ihsan kavramıdır. Hz. Peygamber (s.a.s) ihsan kavramını şöyle tanımlamıștır; “İhsan, Allah'ı görüyormuşçasına kulluk etmendir. Her ne kadar sen o'nu görmüyorsan da o seni görüyor." ${ }^{50}$ Sûfiler ise, kişinin ihsana ulaşabilmesi için haller ve makamlar başlığı altında ele aldıkları birtakım aşamalardan geçmesi gerektiğini ifade eder ve bu süreci seyr u sülûk olarak adlandırır. Bu mücâhedenin asıl amacı en iyi ahlâka ulaşmak olduğu için seyr u sülûk başka bir ifade ile kulun ahlâklanma sürecini kapsar. Serrâc bu bilgiler doğrultusunda ihsanın ahlâk manasında olması hasebiyle tasavvufun alanın da ahlâk olduğunu ifade ederek din bilimleri arasında tasavvufa meșru bir zemin belirlemiş olur. ${ }^{51}$

Cibril hadisinden hareketle tasavvufun alanını ahlâk olarak belirleyen Serrâc'a göre ilm-i bâtın şeklinde ele aldığı tasavvufun amacının İslam ahlâk değerlerini hayata geçirme olduğu söylenebilir. ${ }^{52} \mathrm{Bu}$ açıdan bakıldığında Serrâc'ın eseri dâhil tasavvuf eserlerinde ibâdât ve

45 Ekrem Demirli, "Tasavvuf Araştırmalarında Dönemlendirme Sorunu: Din Bilimleri ile Metafizik Arasında Tasavvufun İlim Olma Mücadelesi", Nazariyat İslâm Felsefe ve Bilim Tarihi Araştırmaları Dergisi 2/4 (Nisan 2016), 1-29.

46 Ekrem Demirli, Sadreddin Konevî'de Bilgi ve Varlık (İstanbul: Kapı Yayınları, 2015), 63-66.

47 Bașer, Şeriat ve Hakikat, 223.

48 Kelâbâzî, Ta'arruf, 46.

49 Serrâc, el-Lüma', 8.

50 Müslim, "İman", 1.

51 Serrâc, el-Lüma', 14.

52 Hacı Bayram Başer, Ebû Nasr Serrâc et-Tûsî’nin Tasavvuf Anlayışı (İstanbul: İstanbul Üniversitesi, Sosyal Bilimler Enstitüsü, Yüksek Lisans Tezi, 2009), 74. 
muâmelât bahislerinin ahlâkî boyutları 'Âdâb’ bașlığı altında sûfilere has birtakım kurallar ile ele alınmasının sebebi anlaşılmış olur. Âdâb kelimesinin müfredi olan edep kelimesi hakkında muhtelif rivayetler bulunsa da genel mânada kabul edilen ise onun, "iyi tutum, dâvet, incelik ve kibarlık" mânalarına gelmesinin yanı sıra bir cemiyette örf ve âdete dönüşmüş iyi tutumlar ve bunları kazandıran bilgi mahiyetinde ifade edilen kavram olarak telakki edilir. ${ }^{53}$ Buna göre tasavvuf âdâbı sûfilerin kendilerince ahlâkı anlama ve uygulaması olarak düşünmek doğru olacaktır. Serrâc da Âdâb bahsine en geniş bölümü ayırdığı el-Lüma'da sûfilerin kendilerine has âdâb kuralları ile bir yandan toplumdaki dindar insanlardan kendilerini ayrıștırırken bir yandan da tasavvufun içeriğini bozan ibâhîlerden farklı olduklarını ispat eder. ${ }^{54}$ Bu ayrıştırmaya ek olarak Serrâc sûfiler arasında da ahlâk anlayışı açısından bir hiyerarşi mevcut olduğunu söyler. Bu meyanda Serrâc insanları ahlâkî yaklaşımları açısından üç gruba ayırır. Bunlardan ilki dünya ehlinin âdâb anlayışıdır ki bunun da "kültürlü olmak" başlı̆ğ altında belâgat, fesâhat ve şiir ezberleme gibi muhtelif sanatsal faaliyetleri içerir. İkinci grup ise dindarları temsil eder ki Serrâc'a göre bu dindarlar sûfilerdir. Bu grubu temsil eden kimseler şüpheli şeylerden kaçınma, nefsi riyazet ve mücâhede ile terbiye etme uygulamalarını gerçekleștirirler. Üçüncü olan son gruba ise, Serrâc'ın havâs olarak nitelendirdiği sûfiler içerisindeki belirli seçkin kimseleri temsil eder. Bu kimseler sırlara riâyetkâr olmak, hâl ve vakti muhâfaza, kalp temizliği ve vuslat anlarında edebe sarılmak gibi anlayışları mevcuttur. ${ }^{55}$ Her ne kadar bir derecelenmeden bahsetse de her bir grubun ortak yönüne dikkat çekmek için Sehl'in "Ancak nefsini edeple yenmesini bilen Allah'a ihlasla amel edebilir" 56 sözünü paylaşır. Buradaki genel ilke ise "ihlaslı olmak" şeklinde kabul edilir.

Tasavvufta âdâb konuları nefsi terbiye etme yollarının gelişmesine en önemli katlı sağlayan bölüm olmuştur. Çalışmanın ilk aşamasında kelam açısından ele alınan bilgi-eylem problematiğine tasavvufta âdâb bahsiyle zorunlu olarak geniş katkılar sağlanır. Nitekim bilginin eylemi getirmesi gerekliliği herkes tarafından kabul gören bir fikir olduğu bilinir. Bu meyanda sûfilerin sair düşünürlerden farklı olarak yaklaşımları ise bilginin eylemi, eylemin ise tekrar yeni bir bilgiyi getirme döngüsüdür. Sûfilerin hadiseyi bu cihetten ele alması dini hayatın uygulamalarına hatırı sayılır bir şekilde zenginlik katar. ${ }^{57}$ Bu çerçeveden bakıldığında Serrâc'ın âdâb bahsinde ele aldığı mühim olan bir diğer yaklaşım ise, bilgi-eylem ilişkisinin kurulması gerektiğidir. Bu doğrultuda aktarmıș olduğu sûfi olan Celâcilî Basrî șu sözü "Tevhid imanı, iman şeriatı, șeriat ise edebi gerektirir. Edebi olmayanın șeriatı, șeriatı olmayanın da imanı yoktur"58 sûfilerin iman-ahlâk ilişkisindeki yaklaşımlarını beyan eder niteliktedir. Bu söz gereğince tevhidin gerçekleşmesinin nihai koşulu edeblenme olduğu gibi edebi bilmek için de şeriat vazgeçilmez bir unsur olarak görülür. Bir başka ifade ile Serrâc'a göre edeblenmenin hâsıl olması ancak o ilme vakıf olmak ile gerçekleşir. Serrâc edebin önemini tafsilatlandırırken $\mathrm{Hz}$. Peygamberin "Hiçbir baba evladına edebden daha değerli bir armağan veremez" 59 hadîs-i şerifine yer vererek onun ümmetine bırakmış olduğu en mühim şeyin edeb olduğuna dikkat çeker. Serrâc'ın bu yaklașımı ile tasavvufu Hz. Peygamberin yașayıș biçimi olarak sıfatlandırdığı ve böylelikle din ilimleri arasında tasavvufa meşru bir alan inşa ettiği kabul edilir. Nihayetinde Serrâc için tasavvuf Hz. Peygamberin yaşam tarzının günümüze taşıyan bir usul olduğu söylenebilir. 60

Tasavvufu diğer din bilimleri arasına girebilmesi için çalışan Serrâc, tasavvufun alanını ahlâk olarak belirledikten sonra onun yöntemi hakkında bilgi vermeye başlar. Bahsedilen yöntem pratik ve teorik şeklinde nitelendirmiş olan iki aşamadan oluşur; bunlardan ilki bilginin elde edilmesiyle ilișkili yöntem ki bu tasfiyedir. İlk așama olan tasfiye, nefsin riyâzet ve mücâhede gibi çeşitli uygulamalar vasıtasıyla arındırılmasını sağlamakla gerçekleşir. Sûfilere göre bunu gerçekleştirmek için sair insanlardan daha fazla nafile ibadetlerin üzerinde durulması

53 Mustafa Çağrıcı, "Edep", Türkiye Diyanet Vakfı İslam Ansiklopedisi (İstanbul: TDV Yayınları, 1989), 10/412414.

54 Serrâc, el-Lüma', 165.

55 Serrâc, el-Lüma', 164.

56 Serrâc, el-Lüma', 164.

57 Başer, Şeriat ve Hakikat, 290.

58 Serrâc, el-Lüma', 290.

59 Ahmed b. Hanbel, el-Müsned, 4/77.

60 Bașer, Ebû Nasr Serrâc et-Tûsî'nin Tasavvuf Anlayışı, 77. 
gerekir. Tasavvufun kurb-ı nevâfile bu derece önem göstermesi onun daha sonra nafile ibadetleri savunan akım olarak bilinmesine sebebiyet verir.61 İkinci aşama ise, elde edilen verileri hakiki manada bilgiye dönüştüren yöntem olan istinbâttır. ${ }^{62}$ Serrâc bu ikinci aşama olan istinbât yöntemini ele alırken her ilmin kendine göre Kur'an-ı Kerim ve sünneti anlama ve onlardan delil getirme usullerinin olduğunu izah eder. Ona göre tasavvuf dâhil ilimlerin ortak olarak kullandıkları yöntem "istinbât" yöntemidir. Kelime manası kuyudan su çekmek ve bir şeyi bulup çıkarmak manasına gelen istinbat, Kur'an-ı Kerim'de bir yerde "Rasûl'e ve içlerinden işten anlayan yetkili bir kimseye götürselerdi, onların arasından ișten anlayanlar, onun ne olduğunu bilirlerdi." 63 olarak geçer ve "bir işin iç yüzünü, gerçeğini fehmetmek ve düşünmeyi icap eden kapalı bir haberden kastedilen mânaya ulaşmak" anlamına gelir. ${ }^{64}$ Serrâc ayette geçen 'istinbat' kelimesinin ilm-i bâtın olduğunu ondan maksadın da tasavvuf olduğunu ifade eder. Buna ek olarak Serrâc 'istinbat' edilen şeyler manasına gelen 'müstenbetât' hakkında şöyle açıklama yapar. "Müstenbetât nedir diye sorulursa biz ona: Müstenbetât tahkîk ehlinden idrâk sahibi Allah'ın kitabına Rasûlü'nün zâhiren ve bâtınen ittibâ eden kimselerin kitap ve sünnetten çıkardığı hükümlerdir ki, onlarla hem zâhirî hem de bâtınî olarak amel etmek gerekir deriz."65 Yapmıș olduğu açıklamadan görülüyor ki istinbat sadece zâhiren hüküm çıkarma yöntemi değildir, bilakis bunun bâtınî tarafı da mevcuttur.

Serrâc'ın tasavvufu ilm-i bâtın olarak tanımlaması hiç şüphesiz onun model ilim olarak fıkıh ilmini almasının tezahürüdür. Onun yaklaşımına göre fıkıh kulun davranışlarıyla ilgilenmesi hasebiyle zâhir ilim olurken tasavvuf da amellerin iç yüzüne değinerek ahlâkî eğitimi amaçladığı için diğer bir tarafı temsil eden bâtın ilim olur. İstinbat yöntemini kullanmada tasavvufu fikıh ile müșterek kabul eden Serrâc, fakihlerin hüküm çıkarmada hata paylarının olması gibi sûfilerin de hata yapmasını muhtemel görür. Bu meyanda sûfilerin Kur'an-ı Kerim ve sünnetten birtakım istinbatlarının bulunduğunu ve hüküm çıkarmada diğer bilim alanları gibi hak sahibi olduklarını izah eder. Ona göre ilm-i bâtın yani tasavvuf yöntem açısından istinbat konusunda İslam ilimleri ile ortak olsa da onlardan farklı olarak hüküm çıkarmak için daha fazla amel ve zikre yönelirler. Serrâc amel ve zikre yönelmenin gerekliliğine delil olarak "Bildikleriyle amel edenlere Allah bilmediklerini öğretir" anlamına gelen hadîs-i șerifi getirir.66 Bu gayret nihayetinde ilim Allah veçhinden kişiye öğretilir. Serrâc'a göre sûfilerin zâhir ehline nazaran hüküm çıkartırken kurb-ı nevâfile daha fazla önem atfetmesi onların bunu yöntem olarak kullanmalarının yanı sıra kendilerine has bir yöntemlerinin bulunduğunun ve bu meyanda din bilimleri tarafından ilim olarak kabul edilmesi gerektiğinin bir delilidir. ${ }^{67}$

\section{Sonuç}

Genel olarak bakılacak olursa bu araștırmada İslam'ın din bilimleri olarak kabul edilen fıkıh ve kelam alanında ahlâk konusu nasıl ele alındığı ana başlıkları incelenmiş oldu. Ahlâk konusunda Mutezile, Eş'ari ve Mâtürîdî ekollerinde özel bir çalışma yapılmadığı, bundan ziyade ahlâk konusunu daha çok muhtelif bir konunun bağlamı ya da sonucu olarak ele alındığı görüldü. Asgari ahlâk olarak nitelendirilen fıkı alanın da ise ilk olarak şer'i hukukun ahlâk düzleminde belirlendiğini lakin zaman geçtikçe alan otoritesinin ağır basması sebebiyle ahlâkın geri plana düşerek şekilciliğin öne çıkmasına vurgu yapıldı. İslam ilimleri olarak sıfatlandırılan bu iki alanda İslam ahlâkının yer bulmaması toplumda bir zümrenin tepkisini çeker. Tepki nihayetinde kendilerine sûfi diyen bu kimseler şehirlerden ayrılır ve toplumdan yüz çevirir. Makam ve mevkii kerih gören sûfiler toplumun onlara hürmet göstermesi hasebiyle belirli bir mevkie ulașırlar. Tasavvufun toplum nezdinde itibar kazanması niyeti bozuk bazı kimselerin bu yola girmeden bu yolun yolcusuymuş gibi davranmalarına sebebiyet verir. Hadisenin buralara gelmesinden rahatsızlık duyan sûfiler bașta terk edilen şehre tekrar dönülmesi gerektiğini fark

61 Ekrem Demirli, "Zâhirî İlimlerin Otoritesi Karşısında Tasavvuf'un Meșruiyet Arayıșı", İstanbul Üniversitesi Illahiyat Fakültesi Dergisi 15 (2007), 220.

62 Başer, Şeriat ve Hakikat, 236-244.

63 Kur'ân Yolu (Erișim 27 Mayıs 2021), en-Nisâ, 4/83.

64 Ferhat Koca, "İstinbat", Türkiye Diyanet Vakfı İslam Ansiklopedisi (İstanbul: TDV Yayınları, 1989), 23/368369.

65 Serrâc, el-Lüma', 119.

66 Serrâc, el-Lüma', 119.

67 Bașer, Ebû Nasr Serrâc et-Tûsî’nin Tasavvuf Anlayışı, 25. 
ederler. Tasavvuf içerisindeki bu tahrifatın yanı sıra şehirde hâkimiyet fakihlerde iken cemiyet arasında veliye itibar ve ittibanın artması ve bu durumun din âlimlerini rahatsız etmeye başlaması tasavvufun sorgulanması ile sonuçlanır. Bu meyanda sûfilerde kendilerinin ibâhî olarak nitelendirilen kişilerden olmadıklarını ve diğer ilimler gibi bir din bilimi olduklarını ispatlama çabası doğar. Cüneyd-i Bağdâdî ile başlayan bu süreç onu takip eden Serrâc, Kelâbâzî, Kuşeyrî ve Hücvîrî ile devam eder. Bu süreçte görülmüş oldu ki; tasavvuf sadece riyazet ve mücâhededen ibaret değildir. Bunlar sadece onun yönteminin ilk aşamasıdır. Yöntemlerinin ikincisi aşaması ise fıkıh ilminin de yöntemi olan istinbat yöntemidir. Flkıh ve tasavvufu bir telakki eden Serrâc'ın istinbat yöntemi üzerinden fikha zâhir ilmi, tasavvufa da bâtın ilmi nitelendirmesi yaptığı izah edildi. Serrâc İslam ilimleri arasında tasavvufun yerini ahlâk ile belirledikten sonra tasavvufun amacının Hz. Peygamberin hayat biçimini Müslümanlara her dönemde ulaştırma olduğunu ifade eder. Âdâb bölümünün tasavvuf eserlerindeki mahiyeti burada ortaya çıkar. Bilgi-eylem ilişkisini sıkı tutan sûfilerin bilgi ve istinbat yolları onların âdâbı anlayış şekillerine göre farklılık kazanır. Bu sebeple tasavvuf eserlerinde âdâb bahsini incelemek tasavvufun iddiasına delil bulmak anlamına gelir. Âdâb bölümüne bu mahiyette bakıldığında Serrâc'in el-Lüma eserinde neden en geniş bahsi âdâb konusuna tahsis ettiği anlaşılmış olur.

\section{Kaynakça}

Ahmed b. Hanbel, Ebû Abdillâh Ahmed b. Muhammed b. Hanbel eş-Şeybânî. el-Müsned. nşr. Ebû Hâcir Muhammed Saîd Besyûnî. Beyrut: y.y., 1405/1985.

Arıcı, Mustakim. "İlimler Tasnifi Literatüründe Ahlâk İlmi". Mukaddime 7/1 (2016), 1-29.

Arslan, Hulusi. "Ahlâkî Değerlerin Nesnelliği ve Öznelliği Açısından Mu'tezile ve Eş'arîlik". Hikmet Yurdu Düşünce-Yorum Sosyal Bilimler Araștırma Dergisi 9/17 (2016), 9-19.

Babacan, Hacer Nur. Erken Dönem Tasavvufunda Akıl-Ahlak İlişkisi. İstanbul: İstanbul Üniversitesi, Sosyal Bilimler Enstitüsü, Yüksek Lisans Tezi, 2019.

Bardakoğlu, Ali. "Ahlâkın Fıkıh Kuralları Arasında Buharlașması". Eskiyeni 35 (2017), 51-94.

Başer, Hacı Bayram. Ebû Nasr Serrâc et-Tûsînin Tasavvuf Anlayışı. İstanbul Üniversitesi, Sosyal Bilimler Enstitüsü, Yüksek Lisans Tezi, 2009.

Başer, Hacı Bayram. Şeriat ve Hakikat. İstanbul: Klasik Yayınları, 2017.

Cüveynî. Kitâbü'l-İrşâd İnanç Esasları Kılavuzu. çev. Adnan Bülent Baloğlu vd. Ankara: Türkiye Diyanet Vakfı Yayınları, 3. Basım, 2016.

Çağrıcı, Mustafa. "Edep". İstanbul: TDV İslam Ansiklopedisi, 1994.

Çağrıcı, Mustafa. "Ahlâk". İstanbul: TDV İslam Ansiklopedisi, 1989.

Çağrıcı, Mustafa. İslam Düşüncesinde Ahlâk. İstanbul: Dem Yayınları, 8. Basım, 2018.

Demirli, Ekrem. İslam Metafiziğinde Tanrı ve İnsan: İbnü'l Arabî ve Vahdet-i Vücûd Geleneği. İstanbul: Alfa Yayınları, 1. Basım, 2017.

Demirli, Ekrem. "Tasavvuf Araștırmalarında Dönemlendirme Sorunu: Din Bilimleri ile Metafizik Arasında Tasavvufun İlim Olma Mücadelesi". Nazariyat İslâm Felsefe ve Bilim Tarihi Araştırmaları Dergisi 2/4 (Nisan 2016), 1-29.

Demirli, Ekrem. Sadreddin Konevî'de Bilgi ve Varlık. İstanbul: Kapı Yayınları, 2015.

Demirli, Ekrem. "Zâhirî İlimlerin Otoritesi Karşısında Tasavvuf'un Meşruiyet Arayıșı". İstanbul Üniversitesi İlahiyat Fakültesi Dergisi 15 (2007), 219-244.

Demirli, Ekrem. "Klasik Düşünce Okulu- Hucviri Keşfü’l Mahcub”. Youtube. Yayın Tarihi 18 Mart 2019. https://www.youtube.com/watch?v=t_P-e6BgcRo

Doğan, Lütfi-Kutluay, Yaşar. "Hasan Basrî'nin Kader Hakkında Halife Abdülmelik b. Mervan'a Mektubu". Ankara Üniversitesi İlahiyat Fakültesi Dergisi 3/3 75-84. 
Eş'arî, Ebû'l-Hasan. el-İbâne ve Usûlü Ehli's-Sünnet Eş'arî Akâidi. çev. Ramazan Biçer. İstanbul: Gelenek Yayıncılık, 1. Basım, 2010.

İbiş, Fatih. "Mâtürîdî’de İman-Ahlâk İlişskisi". Kelam Araştırmaları Dergisi 13/2 (2015), 717-734.

İmam Mâlik, Ebû Abdillâh Mâlik b. Enes el-Asbahî. el-Muvatța’. nşr. Abdüvehhâb Abdüllatîf. Kahire: y.y., 1382/1962.

Kazanç, Fethi Kerim. "Mutezile Kelam Sisteminde Ahlâk Tasavvuru: Kâdî Abdulcebbâr Ekseninde Bir Değerlendirme"". Journal of Islamic Research 27/3 (2016), 280-310.

Kelâbâzî. Doğuş Devrinde Tasavvuf: Ta'arruf. çev. Süleyman Uludağ. İstanbul: Dergâh Yayınları, 3. Basım, 2013.

Koca, Ferhat. "İstinbat". İstanbul: TDV İslam Ansiklopedisi, 2001.

Mâtürîdî, Ebû Mansûr. Kitâbü't-Tevhîd. çev. Bekir Topalğlu. Ankara: İSAM Yayınları, 10. Basım, 2017.

Mekkî, Ebû Tâlib. Kalplerin Azığı. çev. Muharrem Tan. 2. İstanbul: İz Yayıncılık, 3. Basım, 2018.

Melchert, Christopher. Sünnî Düşüncenin Teşekkülü. çev. Ali Hakan Çavuşoğlu. İstanbul: Klasik Yayınları, 2. Basım, 2018.

Muhâsibî, Hâris. Kalp Hayatı. çev. Abdülhakim Yüce. İstanbul: Ișılk Yayınları, 2005.

Müslim, Ebü'l-Hüseyn Müslim b. el-Haccâc. el-Câmi'u'ș-șaḥihh. nşr. Muhammed Fuâd Abdülbâkī. Kahire: y.y., 1374-75/1955-56.

Sâbûnî, Nûreddin. Mâtürîdiyye Akaidi. çev. Bekir Topaloğlu. İstanbul: İFAV Yayınları, 17. Basım, 2017.

Serrâc, Ebû Nasr. İslâm Tasavvufu: el-Lüma'. çev. H. Kamil Yılmaz. İstanbul: Erkam Yayınları, 2016.

Tirmizî, Hakîm. Kalbin Anlamı: Beyânü'l-Fark. çev. Ekrem Demirli İstanbul: Hayy Kitap, 3. Basım, 2013.

Türker, Ömer. Ahlâk. İstanbul: Ketebe Yayınları, 2. Basım, 2020.

Yaman, Ahmet. "Fıkıh-Ahlâk İlişkisi İslâm Amelî Ahlâkının İlke ve Uygulamaları Çerçevesinde Bir Giriş". Usul İslam Araştırmaları 9/9 (2008), 87-118. 